\title{
Ailelerin Çocuklarını Spora Gönderme Sebeplerinin Belirlenmesi: Pilot Çalışma*
}

\author{
Reasons of Parents Why Children Participate To Sports: A Pilot Study
}

\author{
Hüseyin GÖKÇE ${ }^{1 \dagger}$ \\ Kenan KEÇECİ ${ }^{2}$
}

ORİJINAL ARAŞTIRMA

ORIGINAL RESEARCH

Alper YILDIZ 3

${ }^{1}$ Pamukkale Üniversitesi, Denizli https://orcid.org/ 0000-0001-9250-0317

${ }^{2}$ Pamukkale Üniversitesi, Denizli https://orcid.org/0000-0002-8522-5764

${ }^{3}$ Pamukkale Üniversitesi, Denizli

https://orcid.org/0000-0003-1158-7997

\section{$\ddot{O} \mathbf{z}$}

$\mathrm{Bu}$ çalışma, çocukları farklı branşlarda spora devam eden ailelerin çocuklarını spora gönderme sebeplerinin belirlenmesi amacıyla geliștirilmesi, bu amaçla planlanan ölçek geliştirilmesi için pilot çalışma olarak yapılmıştır. Bunun sebebi ise mevcut şartlarda çocukların spora devam edebilmesini hangi koşullarda sağladıklarının belirlenerek, çocukları spora devam edemeyen çocukların velileriyle paylaşılması ve hizmet sunma konumunda bulunan kulüpler, spor okulları, antrenörler, eğitmenler vb. unsurların hizmetlerini geliştirmesi amacıyla çalışmanın önemli olduğu düşünülmektedir. Çalışmanın evrenini 9-16 yaş arası en az 6 aydır spor yapan ve lisanslı olması göz önünde bulundurulan sporcuların velileri oluşturmaktadır. Bu amaçla Denizli ilinde faaliyet gösteren farklı branşlardaki kulüpler ve velilerle görüşülmüş çalışmaya katılmayı kabul eden 378 veli çalışmaya dahil edilmiştir. Araştırmacı tarafindan alan yazın, uzman ve antrenörlerin de görüşü alınarak hazırlanan 16 maddeden oluşan anket ve bilgi formu sporcu velilerine dağıtılmıştır. Ebeveynlerin vermiş oldukları cevaplar tanımlayıcı değerler tablosu ve frekans yüzdeleri ile hesaplanmıştır. Spor yapan çocukların \%27'si kadın, \%73'ü erkektir Spor yapan çocukların ailelerinin fiziksek aktiviteye katılımlarında durum ise; fiziksel aktivite yapan $\% 57$, yapmayan $\% 43$ 'tür. Çocukların devam ettikleri spor branşına bakıldığında \%28 yüzme, \%28 basketbol ve $\% 29$ futbol ve \%15 tenis oluşturmaktadır. Spora gönderme sebeplerinin çocuğun spordan para kazanması olup olmadığının sorulduğu ifadede durum ise \%24'ü katılmakta, \%33'ü kararsız ve \%43'ü katılmamaktadır. Bulgular incelendiğinde çocuklarını spora gönderen velilerin kendilerinin de fiziksel olarak aktif oldukları, daha çok kendi imkânlarıyla çocuklarını spora götürüp getirdikleri, spora göndermelerindeki amaçları olarak; çocuklarının sağlıklı olması, stresten uzaklaşması ve sporcu olmasını istediklerini ancak çocuklarını spora göndermede çocuğunun spordan para kazanmasının çok önemli bir faktör olmadığı görülmektedir.

Anahtar Kelimeler: Spor yapan çocuk, Aile, Spora katılım.

\section{Yayın Bilgisi}

Gönderi Tarihi: 14.11 .2019

Kabul Tarihi: 30.12.2019

Online Yayın Tarihi: 31.12.2019

DOI: $10.33459 /$ cbubesbd.647001

\begin{abstract}
This study was designed to construct a scale that would determine reasons of parents why they have their children participate to sport. Once detecting purposes, expectations, problems, and hardships of parents; service providers such as clubs, sport courses, coaches, or teachers may benefit from this study. Population of this study consisted of parents of children who are aged between 9-16 and at least participated to sport for 6 months. 378 parents from Denizli city whose children participate to sport from various clubs in different sport branches participated to the study. With the help of literature, coaches, and experts a 16-item scale form was generated by there searcher. The scale and demographic information form was handed out to parents. Parents' answers were analyzed by using frequency analysis and descriptive statistics.: $48 \%$ of participants were mothers while $51 \%$ of them were fathers. Among children, $27 \%$ of them were women and $73 \%$ were men Parents are participating to physical activity with $57 \%$, while $43 \%$ of them are not participating to regular physical activity. Branches of the children are respectively; $28 \%$ swimming, $28 \%$ basketball, $29 \%$ soccerand $\% 15$ tennis. $24 \%$ of parents wanted their children earn Money through sport where as $43 \%$ disagreed. Consequently, findings reflected that parents are physically active and take their kids to sports center by their selves. By having their children participate to sport they aim to keep their kids healthy and out of stress. They wanted their kids to be Professional athletes; however, they don't think that gaining Money out of sport is an important factor.
\end{abstract}

Keywords: Athlete child, Family, Sport attendance.

\footnotetext{
* Bu çalışma 11-14 Nisan 2019 tarihleri arasında Bodrum/Muğla'da düzenlenen II. Uluslararası Rekreasyon ve Spor Yönetimi Kongresi'nde sözel bildiri olarak sunulmuştur.

† Sorumlu yazar: Hüseyin Gökçe, hgokce@pau.edu.tr
} 


\section{GİRIŞ}

Günümüzde hızla gelişen teknoloji ve yaşam şartları insan gücüne dayanan ihtiyacı azaltmış ve bunun sonucu olarak insan yapısına aykırı bir durum ortaya çıkmıştır (Kale, 1994; Akt. Yücel, 2004 ). Böylece iş hayatı ve sosyal çevreden gelen baskılar, stres ve bu stresler sonucu ortaya çıkan hastalıklar olumsuz durumların gündeme gelmesine sebep olmuştur. Spor, bu tehlikelere karşı dinamik, aktif, yaşam streslerinden uzak bir ortam yaratarak her yaştan bireye hem sağlıklı bir yaşam biçimi kazandırmakta hem de bireylerin eğlenerek sosyalleşmesini sağlamaktadır (Kotan ve ark., 2009). Bunun yanında spor, bireyin kişilik gelişimine etkisi (Yaman, Yazan ve Türkmen, 2003) öz-yeterlik (Balyan, 2009), problem çözme becerisi ve depresyon üzerine (Canan ve Ataoğlu, 2010), olumlu katkı sağlayan bir araçtır. Günümüzde spor, ilk başta çok önemli bir kitle eğitim aracıdır. Bir eğitim aracı olan spor, kişisel olarak sağlı̆̆ın yanında, moral verimliliği ve karakter gelişimini, milli yönden ise; dinamik, sağlam, güçlü, ortak duygu davranışlarını yükselten ve ülkeler arası prestij için rekabet ortamı oluşturan önemli bir olgudur (Küçük ve Koç, 2004). Spor, insanı fiziksel olarak geliştirdiği gibi oyunlar, hareketler, aktiviteler, yarışmalar aracılığıyla aynı zamanda insan seviyesini, kültürünü, davranış niteliğini, düşünce yapısını belirleyen önemli bir bilim dalıdır (Güven ve Demirhan, 2006). Spor, bireyin kendini disipline ederken karşılaşacağı psikolojik ve fizyolojik sorunları aşmasına yardım eder. Sporun uluslararası dostluk, barış, rekabet ve prestij ile ülke ekonomisine getirdiği olumlu katkılarda vardır (Açıkada ve Ergen, 1990). Spor sistem, disiplin, hedef, başarı kombinasyonudur ve çocuklarının okul başarısıyla ilgili endişelenen sistemli, disiplinli çalışmasını ve sosyalleşmesini isteyen ailelere uzmanların ilk önerisi spor eğitimidir (Amman, İkizler ve Karagözoğlu, 2000). Çocukluk veya ergenlik döneminde bireyin spora yönlendirilip, kötü alışkanlıklardan korunmasını ve enerjisini olumlu yönde kullanılmasını sağlamak; bireyin sosyal yönden gelişmesini ve kendine olan güven problemini aşıp güven duygusunun artmasını sağlayacaktır (Akcan ve Bulgu, 2012; Eyüboğlu, 2012). Eğer birey bu süreçte öğretmeni tarafindan da desteklenirse başarıya daha kolay ulaşacak ve derslerindeki ivme sporla eşgüdümlü bir şekilde yükselecektir. Bireyler spor aracılığıyla bir gruba veya bir takıma dahil olarak yalnızlık duygusundan uzaklaşır, grubun içinde bulunup coşku, sevinç, üzüntü gibi hisleri yaşayarak sosyalleşme sürecine katkıda bulunur. $\mathrm{Bu}$ sosyalleşme süresi ilk kurum olan ailede başlar. Aile, tüm toplumda bütün diğer kurumların, işleyebilmeleri için katkısına muhtaç oldukları bir müessesedir (Akcan ve Bulgu, 2012). Psikolojik gelişme büyük ölçüde ailenin etkisiyle şekillenir. Spora ilgi duyan ebeveynlerin çocuklarını da 
spor yapmaya gönderdikleri ya da bu konuda teşvik ettikleri bilinmektedir (Amman ve ark., 2000). Spor ilköğretim gibi küçük yaşta ve aile de verilmelidir. Örneğin aileler küçük yaşta çocuklarını spor salonlarına götürüp yarışmaları izletip çocuklarının sporla tanışmasını ve onların spor konusunda güdülenmesini sağlaması gerekir (Nirun, 1990). Aynı zamanda çocukların spor yaparken ailesini yanında görmesi ona destek olacaktır ve ailesiyle paylaşacak olduğu konular neticesinde iletişimi artacak ve aile bağları güçlenecektir (Öztürk, 1998). Yetişkinlikte ortaya çıkan birçok ciddi hastalığın temeli de küçük yaşlara dayanmaktadır (Thompson ve ark., 2005). Çocukların sağlığında stres, aile içi sorunlar, düzensiz ve yanlış beslenme alışkanlıkları aktivite eksikliğinin bir sonucu olarak önemli risk faktörü doğurmaktadır (Opper ve ark., 2005; Akt. Pehlivan, 2009). Yapılan çalışmalarda fiziksel aktivite düzeyi ile sigara içme ve alkol kullanma arasında anlamlı bir iliş̧ki bulunmuştur (Usher. Jackson, \& O'Brien 2007). Aileler, göndermiş olduğu spor aktiviteleriyle çocuklarını uyuşturucu, alkol, kumar alışkanlıkları gibi birçok yanlış davranışlardan uzak tutmayı amaçlamışlardır, spor gençlerin saldırganlık duygusunun ve cinsiyet içgüdüsünün bir araya gelerek dinamik enerjisinin en olumlu şekilde çıkış bulduğu yoldur (Hergüner, 1991). Sporun yararlı bir faaliyet olduğunu bütün bunlar ortaya koymaktadır buna rağmen toplumumuzda kız çocukları ve kadınlar için spor, bir lüks olarak görülmüş ve daha çok erkeklere yönelik bir etkinlik olarak yorumlanmıştır; oysa kadın, anne olarak aile ile toplum arasında en sağlam köprüdür (Erkal, 1982). Annenin rolü, çocuğun ilgilerinin doğması ve gelişmesinde oldukça önemli bir etkendir (Güzel, 1990). Çocukların üstleneceği görevlerde, kadının ruhsal ve fiziksel olarak sağlıklı olması gereklidir (Cotta, 1988; Akt. Hergüner, 1991). Bunun için de, düzenli olarak spor yapmak sağlık, ruhsal, fiziksel, duyuşşal ve psikolojik olarak kendini olumlu motive etmesini sağlayacak ve çocuğunun da spora katılmasında ve yönlenmesinde o derece destek olup yol gösterecektir.

Günümüzde çocuklar için sporun önemini bilinse de farklı sebeplerden dolayı çocukların spor yapma oranının düşük olduğunu görmekteyiz. Mevcut olumsuzluklar içinde çocuklarının spor yapmasını sağlayan, destekleyen velilerin motivasyonlarını öğrenmek, çocuklarını spora gönderen velilerin beklenti ve isteklerini belirlemeye yönelik bir ölçek geliştirmek amacıyla bu pilot çalışma gerçekleştirilmiştir. Bu beklenti ve isteklerin belirlenmesinden sonra velilere verilecek eğitimlerin içerikleri daha bilinçli olarak belirlenebilecektir. Ayrıca bu beklenti ve isteklerden spor alanında çalışan kişilerin haberdar olmaları dolayısıyla daha uzun soluklu birliktelikler oluşturulabileceği 
düşünülmektedir. Son olarak bu konuyla ilgili yapılacak diğer çalışmalara da rehber olması açısından çalışmanın önemli olduğu düşünülmektedir.

\section{YÖNTEM}

Araştırma deseni, nicel-betimsel yöntem ile hazırlanmıştır. Araştırmanın evrenini Denizli ili Merkezefendi ve Pamukkale ilçelerinde yaşayan 9-16 yaş arasında en az 6 aydır spora aktif devam eden ve lisanslı olması göz önünde bulundurulan sporcu velileri oluşmaktadır. Araştırmanın evreni toplam 30.027 kişidir. Örneklem olarak dahil edilecek katılımcılar Yazıcıoğlu ve Erdoğan'ın (2004) örneklem belirleme tablosunda ,05 hata payına göre 378 olarak belirlenmiştir. Katılımcıların \%51'i anne, \%48'i baba ve \%1'i diğer olarak oluşmaktadır.

\section{Veri Toplama Araçları}

Veri toplama araçları olarak katılımcıların çocuklarının yaşı, velinin spor yapan ve yapmayan çocuk sayısı, çocuklarının cinsiyeti, çocuklarının spor branşları, çocuklarının okulda branşıyla ilgili antrenman yapabilme durumları, çocuğun haftada yaptığı antrenman sayısından oluşan araştırmacı tarafından hazırlanan kişisel bilgi formu ve araştırmacı tarafından uzmanların ve antrenörlerin de görüşü alınarak konuyu ölçmeye yönelik 16 maddeden oluşan anket hazırlanmıştır. Velilerin çocuklarını spora gönderme sebepleri "Katılmıyorum (1)", "Kararsızım (2)”, “Katıllıyorum (3)”, şeklindeki 3'lü Likert tipi ölçek üzerinde değerlendirilmiştir.

\section{Verilerin Analizi}

Toplanan veriler istatistik programı ile değerlendirilmiştir. Verilere ait bulgular, minimummaksimum değerler, ortalamalar, frekans ve yüzde dağılımları karşıllaştırmalı olarak tablolar halinde verilmiştir. 
Gökçe, H., Keçeci, K., Yıldız, A. (2019). Ailelerin çocuklarını spora gönderme sebeplerinin belirlenmesi: Pilot çalışma. CBÜ Beden Ĕgitimi ve Spor Bilimleri Dergisi, 14 (2), 356-366.

\section{BULGULAR}

\section{Demografik Bulgular}

Tablo 1. Araştırmaya katılan velilerin demografik özelliklerine göre dağılımları

\begin{tabular}{|c|c|c|c|}
\hline Sorular & Katılımcılar & $\mathbf{N}$ & $\%$ \\
\hline \multirow[t]{3}{*}{ Veli } & Anne & 194 & 51 \\
\hline & Baba & 182 & 48 \\
\hline & Diğer (büyükbaba vs.) & 2 & 1 \\
\hline \multirow[t]{2}{*}{ Çocuk cinsiyet } & $\mathrm{K} 1 \mathrm{z}$ & 100 & 27 \\
\hline & Erkek & 278 & 73 \\
\hline \multirow{2}{*}{ Çocuğun devam ettiği okul statüsü } & Devlet & 248 & 66 \\
\hline & Özel & 130 & 34 \\
\hline Çocuğunuzun akademik başarısından & Hayır & 4 & 1 \\
\hline \multirow[t]{2}{*}{ Memnun musunuz? } & Ne iyi ne kötü & 66 & 17 \\
\hline & Evet & 308 & 82 \\
\hline \multirow[t]{4}{*}{ Çocuğunuzun spor branşı nedir? } & Yüzme & 105 & 28 \\
\hline & Futbol & 110 & 29 \\
\hline & Basketbol & 105 & 28 \\
\hline & Tenis & 58 & 15 \\
\hline Okulda branșıyla ilgili antrenman & Evet & 111 & 29 \\
\hline Yapabiliyor mu? & Hayır & 267 & 71 \\
\hline \multirow[t]{7}{*}{ Çocuğunuz antrenmana kimle gidiyor? } & Yalnız & 39 & 10 \\
\hline & Bakıc1-yardımc1 & 5 & 1 \\
\hline & Sporcu aileleri sırayla & 27 & 7 \\
\hline & Anne-baba & 281 & 75 \\
\hline & Büyükanne-büyükbaba & 8 & 2 \\
\hline & Arkadaş & 11 & 3 \\
\hline & Diğer & 7 & 2 \\
\hline \multirow[t]{2}{*}{ Başka çocuğunuz var mı? } & Evet & 283 & 75 \\
\hline & Hayır & 95 & 25 \\
\hline \multirow[t]{2}{*}{ Diğer çocuğunuz spor yapıyor mu? } & Evet & 239 & 63 \\
\hline & Hayır & 139 & 37 \\
\hline \multirow{2}{*}{$\begin{array}{l}\text { Velisi olarak siz düzenli spor } \\
\text { yapabiliyor musunuz? }\end{array}$} & Evet & 216 & 57 \\
\hline & Hayır & 162 & 43 \\
\hline
\end{tabular}

Tablo 2. Ortalama Değerler Tablosu

\begin{tabular}{lr}
\hline Sorular & $\overline{\mathrm{x}}$ \\
\hline Çocuğunuzun yaşı kaçtır? & 11.46 \\
\hline Çocuğunuz kaç aydır spora devam ediyor? & 35.45 \\
\hline Haftada kaç gün antrenman yapıyor? & 3.59 \\
\hline Günde kaç saat antrenman yapıyor? & 1.85 \\
\hline
\end{tabular}


Gökçe, H., Keçeci, K., Yıldız, A. (2019). Ailelerin çocuklarını spora gönderme sebeplerinin belirlenmesi: Pilot çalışma. CBÜ Beden Ĕgitimi ve Spor Bilimleri Dergisi, 14 (2), 356-366.

Araştırmaya katılan ailelerden \%48'i çocukların babası, \%51'i annesi ve \%1’i diğeridir(büyükbaba vs.). Spor yapan çocukların \%27’i kadın, \%73’ü erkektir. Spor yapan çocukların \%66'sı devlette \%34'ü özel okulda öğrenim görmektedir. Ailelerin çocuklarının akademik başarısından memnuniyetine gelindiğinde; memnun olanlar; \%82'ye, \%1'dir.Çocukların devam ettikleri spor branşına bakıldığında \%28'i yüzme, \%28'i basketbol, $\% 29$ 'u futbol ve \%15'ini tenis oluşturmaktadır. Çocukların \%29'u okulda branşıyla ilgili antrenman yapabilmekte iken $\% 71$ 'i yapamamaktadır. Spor yapan çocukların \%75'i spora anne ya da babası ile giderken, \%10'u kendileri ulaşımı sağlamaktadır. Spor yapan çocukların ailelerinin fiziksek aktiviteye katılımlarında durum ise; FA yapan \%57, yapmayan \%43'dür. Araştırmaya katılan velilerin çocuklarının yaş ortalaması 11.46. Çocuklar ortalama 35.45 aydır spora devam etmektedir. Çocukların haftada yaptığı antrenmanın ortalaması 3.59 gündür. Çocukların günde yaptığı antrenman saatinin ortalamas 1.85 'dir.

Tablo 3. Çocuklarını spora gönderen velilerin çocuklarını spora gönderme sebeplerinin belirlenmesine ilişkin tanımlayıcı istatistikler

\begin{tabular}{llrr}
\hline Çocuğumun spor yapmasını isterim çünkü; & & $\mathbf{N}$ & $\mathbf{\%}$ \\
\hline 1.Sağlıklı olmasını istediğim için & Katılıyorum & 378 & 100 \\
& Kararsızım & 0 & 0 \\
& Katılmıyorum & 0 & 0 \\
\hline 2.Sporcu olmasını istediğim için & Katılıyorum & 272 & 72 \\
& Kararsızım & 68 & 18 \\
& Katılmıorum & 38 & 10 \\
\hline 3.Rekabetçi olmasını istediğim için & Katılıyorum & 193 & 51 \\
& Kararsızım & 99 & 26 \\
& Katılmıyorum & 86 & 23 \\
\hline 4.Sosyalleşmesini istediğim için & Katılıyorum & 364 & 96 \\
& Kararsızım & 9 & 3 \\
\hline 5.İşbirlikçi ruhunun gelişmesini istediğim için & Katılmıyorum & 5 & 1 \\
\hline 6.Özgüveninin artmasını istediğim için & Katılıyorum & 356 & 94 \\
& Kararsızım & 17 & 5 \\
& Katılmıyorum & 5 & 1 \\
\hline
\end{tabular}


Gökçe, H., Keçeci, K., Yıldız, A. (2019). Ailelerin çocuklarını spora gönderme sebeplerinin belirlenmesi: Pilot çalışma. CBÜ Beden Eğitimi ve Spor Bilimleri Dergisi, 14 (2), 356-366.

Tablo 3. (Devamı) Çocuklarını spora gönderen velilerin çocuklarını spora gönderme sebeplerinin belirlenmesine ilişkin tanımlayıcı istatistikler

\begin{tabular}{|c|c|c|c|}
\hline \multirow[t]{3}{*}{ 7.Spordan para kazanmasını istediğim için } & Katıliyorum & 92 & 24 \\
\hline & Kararsızım & 124 & 33 \\
\hline & Katılmiyorum & 162 & 43 \\
\hline \multirow[t]{3}{*}{ 8.Fairplay(centilmen) davranışlar sergilemesi için } & Katıliyorum & 360 & 95 \\
\hline & Kararsızım & 15 & 4 \\
\hline & Katılmiyorum & 3 & 1 \\
\hline \multirow{3}{*}{$\begin{array}{l}\text { 9.Fiziksel sağllk durumunun iyileşmesini istediğim } \\
\text { için }\end{array}$} & Katıliyorum & 348 & 92 \\
\hline & Kararsızım & 17 & 5 \\
\hline & Katılmiyorum & 13 & 3 \\
\hline \multirow[t]{3}{*}{ 10.Tavsiye( doktor öğretmen vs.) edildiği için } & Katıliyorum & 105 & 28 \\
\hline & Kararsızım & 41 & 11 \\
\hline & Katılmiyorum & 232 & 61 \\
\hline \multirow[t]{3}{*}{ 11.Stresten uzaklaşmasını istediğim için } & Kat1liyorum & 334 & 88 \\
\hline & Kararsızım & 21 & 6 \\
\hline & Katılmiyorum & 23 & 6 \\
\hline \multirow[t]{3}{*}{ 12.Çocuğum istediği için } & Katıliyorum & 362 & 96 \\
\hline & Kararsızım & 9 & 2 \\
\hline & Katılmiyorum & 7 & 2 \\
\hline \multirow[t]{3}{*}{ 13.Kardeş ya da bir yakınından özendiği için } & Kat1liyorum & 67 & 18 \\
\hline & Kararsızım & 55 & 14 \\
\hline & Katılmiyorum & 256 & 68 \\
\hline \multirow[t]{3}{*}{ 14.Kötü alışkanlıklardan uzaklaşmasını istediğim için } & Katıliyorum & 328 & 87 \\
\hline & Kararsızım & 13 & 3 \\
\hline & Katılmiyorum & 37 & 10 \\
\hline \multirow[t]{3}{*}{ 15.Aktif bir birey olmasını istediğim için } & Kat1liyorum & 370 & 93 \\
\hline & Kararsızım & 2 & 2 \\
\hline & Katılmiyorum & 6 & 5 \\
\hline \multirow{3}{*}{$\begin{array}{l}\text { 16. Spor yapmanın prestijli bir iş olduğunu } \\
\text { Düşündüğüm için }\end{array}$} & Katıliyorum & 271 & 72 \\
\hline & Kararsızım & 43 & 11 \\
\hline & Katılmiyorum & 62 & 17 \\
\hline
\end{tabular}

Spor yapan çocukların ailelerinin "çocuğumun spor yapmasını isterim çünkü; sağlıklı olmasını isterim ifadesine katılımcıların tamamı "katılıyorum" ifadesini işaretlemişlerdir. "Çocuğumun sporcu olması için" ifadesindeki cevaplara bakıldığında; katılıyorum diyenler \%72 iken, \%18'i kararsız ve \%10'u katılmamaktadır. Rekabetçi olmasını isteyenlere gelindiğinde durum \%51'i katılmakta, \%26'sı kararsız ve \%23'ü katılmamaktadır. “Çocuğumun sosyalleşmesi için” ifadesine \%96'sı katılırken, \%2'si kararsız ve \%1'i de katılmamaktadır. İşbirlikçi ruhunun gelişmesini isteyenler \%94, kararsız kalanlar \%5 katılmayanlar ise \%1'dir.Ailelerin \%96's1 
çocuğunun özgüveninin artmasını istemekte \%3’ü kararsız kalmakta \%1’i bu duruma katılmamaktadır. Spora gönderme sebeplerinin çocuğun spordan para kazanması olup olmadığının sorulduğu ifadede durum ise \%24'ü katılmakta, \%33’ü kararsız ve \%43'ü katılmamaktadır. Fairplay (centilmenlik/adil oyun) davranış sergilemesini isteyen aileler $\% 95^{\prime}$ 'lik bir orana sahiptir. Spor yapan çocukların ailelerinin \%28'i tavsiye üzerine spora gönderirken, \%11'i kararsız ve $\% 61$ 'i bu duruma katılmamaktadır. Stresten uzaklaşma durumuna ise ailelerin \%88'i katılmakta, \%6'sı kararsız kalmakta ve \%6'sı bu duruma katılmamaktadır. Çocuğu istediği için spora gönderen aileler \%96 iken \%2'si kararsız ve \%2'si katılmamaktadır. Bir başkasından özendiği için gönderen aileler \%18'ini oluştururken \%14'ü kararsız kalmakta ve \%68'i bu duruma katılmamaktadır. Ailelerin \%87'si kötü alışkanlıktan uzak durması için spora göndermekte \%2'si kararsız ve \%11'i katılmamaktadır. Aktif bir birey olmasını isteyen aileler \%93'e, \%5'dir. 'Sporun prestijli bir uğraş olduğunu düşündüğüm için'" ifadesine ise \%72'si katılmakta, \%11'i kararsız kalmakta ve \%17'si katılmamaktadır.

\section{TARTIŞMA ve SONUÇ}

Pehlivan (2009) tarafından gerçekleştirilen "Spora Katılan Çocuklara Yönelik Ailelerin Beklentileri, Çocuklarda Gözlenen Davranış Değişimleri ve Spora Katılımın Önündeki Engeller" adlı çalışmada \% 91.8'i basketbol spor okuluna katılan çocuğun "kendine güven duygusunun arttığını”, \% 87.7'si “arkadaş sayısında artış olduğunu”, \% 87.6's1 “daha çok işbirliği içine girip paylaştığını", \% 87.4'ü “daha sağlıklı göründüğünü” , \% 72.4'ü “madde bağımlılığında azalma olduğunu (sigara, alkol, uyuşturucu v.b.)”, \% 71.7'si stres, kaygı ve saldırgan davranışlarında azalma olduğu sonucuna ulaşılmıştır. Bunun yanında Batmaz ve arkadaşları (2013)'nın "Ortaöğretim Kurumlarında Voleybol Oynayan Sporcuların Spora Yönelik Beklenti ve Memnuniyet Düzeyleri” adlı çalışmalarında da voleybol sporunu üst düzeyde sporcu olmak istediği için yaptıkları görüşünü belirtmişlerdir. Bu bulgular ile bizim çalışmamızdaki bazı bulgular benzerlik göstermektedir. Keskin (2006) "Çocuklarını Spora Yönlendiren Anne ve Babaların Beklentileri” adlı çalışmada da aileler sportif ortamın çocuklarını sigara, alkol ve diğer zararlı alışkanlıklardan uzak tutacağını düşündüğünü belirtirken erkekler \%79,2, bayanlar ise \%75,4 oranlarında görüşlerini ifade etmişlerdir. Öztürk (2016) 'Velilerin Çocuklarını Basketbol Okullarına Gönderme Sebeplerinde Etkili Olan Nedenlerin Tespiti' adlı çalışmada da 
katılımcıların çocuklarını basketbol okullarına göndermelerindeki en önemli nedenlerin çocuklarının sağlıklarını korumak, kendilerine olan özgüvenlerinin gelmesine yardımcı olmak, sorumluluk bilincine sahip olmak, kötü alışkanlıklardan uzaklaşmak, sosyal anlamda gelişebilmek, okul stresinden uzaklaşarak, takım ruhu içinde hareket etmeyi öğrenmek amacıyla gönderildiği saptanmıştır. Ayrıca katılımcıların basketbol okullarına çocuklarını gönderme nedenlerinden ileriki yaşamlarında maddi anlamda kazanç elde edeceği düşüncesinde olmadığı tespit edilmiştir. Bir başka araştırmada Amman ve ark. (2000) spora ilgi duyan anne ve babaların çocuklarını da spor yapmaya teşvik ettiklerini belirtmektedirler. Yapılan diğer çalışmalara bakıldığında da çıan sonuçlar bizim çalışmamız ile örtüşmektedir.

Sonuç olarak, çocukları spora katılım gösteren velilerin; kendilerinin de fiziksel olarak aktif oldukları, daha çok kendi imkânlarıyla çocuklarını spora götürüp getirdikleri, spora göndermedeki amaçlarının; sağlıklı olması, stresten uzaklaşması ve sporcu olması iken, çocuklarının spordan para kazanması ailelerin büyük çoğunluğu için çok önemli bir faktör olarak görülmediği sonucuna ulaşılmıştır. Başka bir soruda ailerler sporu prestijli bir iş olarak gördüklerini belirtirlerken, bu durumun çocuklarının spordan para kazanıp kazanmamasının ötesinde çocuklarının sporla ilgili iş yapmalarına verdikleri değeri göstermektedir.

Çocukların spora katılımının tek başına bir faktör olmadığı, spora devam etmesi için ailelerin büyük bir özveride bulunması ve aynı zamanda kendilerinin de fiziksel olarak aktif olan bireylerin çocuklarının da daha çok spora yönlendirildikleri düşünüldüğünde spor politikalarının sadece çocuk üzerinden değil veli üzerinden de yürütülmesi gerektiği görülmektedir. Spor yapan çocuklar ile spor yapmayan çocukların akademik başarıları karşılaştırılabilir.

Çocuğunu spora gönderen ailelerin; spordan para kazanmasından ziyade sağlıklı olması, stresten uzaklaşması gibi büyük yüzdelerle buna cevap vermiş. Çocuğunu spora gönderen ailelerin durumu bu iken çocuğunu spora göndermeyen ailelerin bu konuda bilgilerinin eksikliği varsayımıyla bilinçlendirilmeleri sağlanabilir. 
Gökçe, H., Keçeci, K., Yıldız, A. (2019). Ailelerin çocuklarını spora gönderme sebeplerinin belirlenmesi: Pilot çalı̧̧ma. CBÜ Beden Eğitimi ve Spor Bilimleri Dergisi, 14 (2), 356-366.

\section{KAYNAKLAR}

Akkurt, M. (2008). Kahramanmaraş'ta yapılan geleneksel güreşlerin tarihsel gelişimi ve toplum tarafindan algılanış biçimleri. Yüksek Lisans Tezi. Kahramanmaraş Sütçü İmam Üniversitesi, Sosyal Bilimler Enstitüsü, Kahramanmaraş.

Açıkada , C., Ergen E. (1990). Bilim ve Spor. Ankara: Büro Tek Ofset Matbaacılık, s:5.

Akcan, F., \& Bulgu, N. (2012). Spora yönelik sosyalizasyon süreci: Lise öğrencileri üzerine bir uygulama. Spor Bilimleri Dergisi, 23(4), 195-206.

Amman, M.T., İkizler, H.C. \& Karagözoğlu, C. (2000). Sporda Sosyal Bilimler. İstanbul: Alfa Yayınevi.

Balyan M (2009): İlköğretim 2. kademe ve ortaöğretim kurumlarındaki öğrencilerin beden ĕ̆itimi dersine yönelik tutumları, sosyal beceri ve özyeterlik düzeylerinin karşılaştırılması. Yayınlanmamış doktora tezi, Ege Üniversitesi, İzmir.

Batmaz, H. Ç., Yıldırım, F., Coşkuner, Z., Karadağ, M., \& Atalı, A. (2013). Ortaöğretim kurumlarında voleybol oynayan sporcuların spora yönelik beklenti ve memnuniyet düzeyleri (Elâzığ ili örneği) özet. E-Journal of New World Sciences Academy, 96.

Beyleroğlu, M. (2001). Elit seviyedeki Türk boksörlerde saldırganlık geni ve retina bozukluklarının incelenmesi, Ankara, Gazi Üniversitesi, Doktora Tezi.

Canan, F., ve Ataoğlu, A. (2010). Anksiyete, depresyon ve problem çözme becerisi algısı üzerine düzenli sporun etkisi. Anatolian Journal of Psychiatry, 11(38), 38-43.

Çağlayan, A., Çalık, F., Sivrikaya, K., Kahveci, M. (2004). 12-15 Yaş grubu spor yapan öğrencilerle spor yapmayan öğrencilerin okul başarıları yönünden karşılaştırılması. 10. ICHBER-SD Avrupa Kongresi | ve SBD 8. Uluslararası Spor Bilimleri Kongresi, Bildiri Kitab1, Antalya, 17-20 Kasim.

Çakmaklı, K. (2002). Aileler İçin Sosyal Hizmet, T.C. Başbakanlık Aile Araştırma Kurumu Başkanlığı yayınları. No: 12 (s.35). İstanbul: Eramet Matbaacilik.

Dönmezer, S. (1984). Sosyoloji, Savaş Yayınları, Ankara, s.214.

Elçi, G. \& Ballı, Ö. M. (2014). Ebeveynlerin çocuklarının serbest zaman aktiviteleri ve spora katılımlarıyla ilgili görüş ve beklentileri. CBÜ Beden Eğitimi ve Spor Bilimleri Dergisi, 6(1). 36-46.

Erdemli, A. (1991). Türk-Alman kültür diyalogunda spor ahlakı ve spor felsefesine yeni yaklaşımlar. İstanbul: Meya Matbaacılık ve Yayımcilik, s.50.

Eyüboğlu, E. (2012). Spor yapan ve yapmayan 12-14 yaş arası ergenlerin öz yeterlik düzeylerinin karşılaştırllması. Haliç Üniversitesi Psikoloji ABD., Uygulamalı Psikoloji Programı, Yayınlanmamış Doktora Tezi., İstanbul. s.72.

Güven, B., \& Demirhan, G. (2006). Beden eğitimi öğretmenlerinin sınıf yönetiminin öğretmen davranışı boyutuna ilişkin görüşleri. Spor Bilimleri Dergisi, 17(4), 158-172.

Güzel, A. (1990) Ailede Çocuk Eğitimi, I. Aile Şurası Bildirileri. Ankara.

Hellstedt, J. C. (1995). Invisible players: a family systems model. In S. Murphy (Ed.), Sport Psychology Interventions (pp. 117146). Champaig, Il: Human Kinetics.

Hergüner, G. (1991). Çocuğun spora yönelmesinde ailenin rolü ve önemi. Ondokuz Mayls Üniversitesi Ĕ̆itim Fakültesi Dergisi, 6(1), 91-95.

Hutchinson, S. L., Baldwin, C. K., \&Caldwell, L. L. (2003). Different iating parent practices related adolescent behavior in the free time context. Journal of Leisure Studies, 35(4), 396-422.

Keskin, V. (2006). Çocuklarını spora yönlendiren anne ve babaların beklentileri. Afyon Kocatepe Üniversitesi, Sağlık Bilimleri Enstitüsü, Yüksek Lisans Tezi. S.112.

Kotan, Ç. (2007). İlköğretim okullarında okuyan sporcu öğrencilerin spor yapmalarında okul ve aile faktörünün etkisi (Sakarya İl Örneği), Yayınlanmamış Yüksek Lisans Tezi. Sakarya. 
Gökçe, H., Keçeci, K., Yıldız, A. (2019). Ailelerin çocuklarını spora gönderme sebeplerinin belirlenmesi: Pilot çalışma. CBÜ Beden Eğitimi ve Spor Bilimleri Dergisi, 14 (2), 356-366.

Kotan, Ç., Hergüner, G. ve Yaman, Ç. (2009). İlköğretim okullarında okuyan sporcu öğrencilerin spor yapmalarında okul ve aile faktörünün etkisi (Sakarya il örneği), Niğde Üniversitesi Beden Ĕ̈itimi ve Spor Bilimleri Dergisi, 3(1): 49-58.

Küçük, V., \& Koç, H. (2004). Psiko-sosyal gelişim süreci içerisinde insan ve spor ilişkisi. Dumlupınar Üniversitesi Sosyal Bilimler Dergisi, 10, 1-12.

Nirun, N. (1990). Sosyoloji. İstanbul: M.E. Basımevi, s.177.

Öztürk, F. (1998). Toplumsal Boyutlarıyla Spor. Ankara: Bağırgan Yayınevi, S., 9, 21 ,48, 51-53, 61-63.

Öztürk, H., Akın A., Damar, D. (2016) Velilerin çocuklarını basketbol okullarına gönderme sebeplerinde etkili olan nedenlerin tespiti. CBÜ Beden Ĕ̈itimi ve Spor Bilimleri Dergisi, 11(1), 1-11.

Pehlivan, Z. (2009). Spora katılan çocuklara yönelik ailelerin beklentileri, çocuklarda gözlenen davranış değişimleri ve spora katılımın önündeki engeller. SPORMETRE Beden Eğitimi ve Spor Bilimleri Dergisi, 7(2), 69-76.

Rutten, E. A., Stams, G. J. J. M., Biesta, G. J. J., Schuengel, C., Dirks, E., Hoeksma, J. B.,(2007). “The contribution of organized you the sport to antisocial and prosocial behavior in adolescent athletes", Journal of Youth Adolescence, 36:255-264.

Thompson, A. M., Rehman, L. A., \& Humbert, M. L. (2005). Factors influencing the physically active leisure of children and youth: A qualitative study. Journal of Leisure Studies, 27(5), 421-438.

Opper, E., Worth, A., Bös, K. (2005). Kinderfitness-kindergesundheit. Bundesgesundheitsbl Gesundheitsforsch Gesundheitsschutz, $48,854-862,23$.

Ussher, M. H., Owen, C. G., Cook, D. G.\& Whincup, P. H. (2007). The relationship between physical activity, sedentary behaviour and psychological wellbeing among adolescents. Social Psychiatry Psychiatr Epidemiol, 42, 851-856, 2007.

Wagner, N., Kirch, W. (2006). Recommendations for he promotion of physicalactivity in children. Journal of Public Health, 14:7175 .

Yazıcıoğlu, Y., ve Erdoğan, S. (2004). SPSS uygulamalı bilimsel araştırma yöntemleri. Ankara: Detay Yayıncılık. (s 53).

Erkal, M. (1990). Türkiye’de boşanmalar ve bazı sapma davranışlar. I. Aile Şûrası Bildirileri, Ankara, s. 212.

Yaman, M., Yazan, T. ve Türkmen, M. (2003). Sporun üniversite adayı öğrencilerinin ataklık ve pratik olma kişilik özellikleri üzerine etkisi. Sakarya Üniversitesi Eğitim Fakültesi Dergisi, 5,16-132.

Yurdakul R.S. (2001), Ana-baba el kitabı. Adana: Nobel Kitabevi, Tayf Ofset, S., 40- 43.

Yücel, M. (2004). Gelişim ve öğrenmenin spor kültürünün oluşmasına etkisi. Doğu Anadolu Bölgesi Araştırmaları, 100-108. 